\title{
DIVERSION AND TRANSFORMATION OF POLICY RESOURCES (SOCIAL AUDIT STUDY ON IMPLEMENTATION OF MASBAGIK TRADITIONAL MARKET RELOCATION)
}

\section{Evi Sukmayeti}

Lecturer of STIA Mataram, Indonesia

Email: evi.sukmayeti@gmail.com

DOI: https://doi.org/10.18196/jgpp.5189

Article Info

Article history:

Received 03 Feb 2018

Revised 20 Feb 2018

Accepted 26 Feb 2018
Keywords: Social Auditing Approach, Diversion, Transformation, Policy Resources.

\section{ABSTRACT}

The revitalization of Pasar Lama Masbagik is a strategic policy of the Government of East Lombok Regency Local Government in 2015, funded by a loan to the Government Investment Center. By relocating traders from the Old Market to Modern Market, as well as expanding and renovation the Old Market for potential new investors, the government hopes to optimize the local assets with supporting transaction convenience for the buyer. However, the policy is considered to be economically unfavorable by target groups that are in fact local people, followed by a series of rejections. The policy began to be implemented in 2016. The models and approaches in public policy analysis in academic field have been using a common methodology. The availability of applied literature has not been generated in academic research. The study of the policy implementation, refered to a social auditing approach, explained how the implementation black box runs in the path as well as with biases (diversion and transformation). Data collection was performed by purposive method and snowball sampling to stakeholders. Document tracking supported in informants determination being the way of triangulating data in addition to observation.The revitalization of the old traditional Masbagik market involved the action of relocating traders to Modern Market of Masbagik and the residents who lived around the market area toward new residence. The process of policy implementation precisely run on the target of time. Meanwhile, the allocation of material resources such as lapak, kiosk, land and financial compensation for the sufferer groups who are traders and residents met some biases (diversion and transformation). Biases caused some target groups to be suffered or being unexpected beneficiaries by relocation

\section{ABSTRAK}

Kebijakan revitalisasi melalui relokasi pedagang Pasar Lama Masbagik merupakan kebijakan strategis Pemerintah Kabupaten Lombok Timur pada tahun 2015 yang didanai dari pinjaman kepada Pusat Investasi Pemerintah. Dengan memindahkan pedagang dari Pasar Lama ke Pasar Masbagik Modern, sekaligus memperluas dan merenovasi Pasar Lama untuk calon investor baru, pemerintah berharap dapat mengoptimalkan asset daerah sekaligus menciptakan kenyamanan bertransaksi untuk 
masyarakatnya. Namun kebijakan tersebut dinilai justru akan merugikan secara ekonomi oleh target groups yang notabene masyarakat lokal, diikuti dengan serangkaian aksi penolakan. Awal 2016, kebijakan tersebut mulai diimplementasikan. Model dan pendekatan dalam analisis kebijakan public di kalangan akademisi selama ini masih menggunakan metodologi yang umum. Tersedianya literature terapan belum banyak diturunkan dalam penelitian yang bertujuan akademik. Studi terhadap implementasi kebijakan ini, menggunakan pendekatan social auditing yang bias (diversi dan transformasi). Pengumpulan data dilakukan secara purposive dan snowball sampling terhadap stakeholder. Penelusuran data dokumen, mendukung penentuan informan dan menjadi salah satu cara dalam triangulasi data selain melakukan observasi. Revitalisasi pasar tradisional Masbagik lama melibatkan aksi relokasi pedagang ke Pasar Masbagik Baru dan warga yang bermukim di sekitar area pasar ke area pemukiman yang baru di desa yang sama. Proses implementasi kebijakan berjalan sesuai dengan target waktu, namun untuk pengalokasian sumber daya materi seperti lapak, kios, lahan dan ganti rugi financial terhadap kelompok penderita yakni pedagang dan warga mengalami beberapa bias (diversi dan transformasi). Bias tersebut di lapangan menjadikan beberapa kelompok target menjadi penderita (dirugikan) atau penerima manfaat yang tak terduga (justru diuntungkan) dengan adanya relokasi.

\section{INTRODUCTION}

Decentralization provides space for Local Government to build the economy according to local perspectives. Various innovations in regional economic policy are aimed at strengthening development financing and enhancing the economic independence or welfare of local communities. The mainstream policy is to attract investors for business expanding in the region. Infrastructure improvement is prepared to support potential investors. Public service reform on business licensing expected to provide stimulus as carrying simply and efficience bussiness growing. Attracting other significance investments, one of them is the revitalization of traditional markets aimed at increasing the output of regional assets for public budget, changing behavior of traditional businessman as well as creating the convenience of transactions for the community. 
In cases of revitalization of traditional markets in various regions, this policy almost never faces rejection, especially by local target traders. Mostly revitalization of traditional markets forced traders to change the pattern of selling, the condition in which business capital must be enlarged. The relatively larger kiosk rental cost as well as the stall facilities that must be prepared or added, causing higher business capital. It usually follows by increasing of several charges and the uncertainty of getting a selling room. Position of strategic selling and already known by a number of buyers also become consideration of merchants who refuse relocation.

In 2015, government of East Lombok regency decided to revitalize traditional market of Masbagik located in strategic location in East Lombok. In addition to the old location at the center of government activities and public services in Masbagik District, this market stands exactly at the crossroads of Lombok Island to Sumbawa Island and connect the island of Java and the mainland of Indonesia to East Nusa Tenggara. Market revitalization budget is allocated through Regional Revenue and Expenditure Budget (APBD) East Lombok 2016. Consequently by the end of 2015, market traders had to be moved.

Initially this regulation became the effort to government for make some utilizing the building of Masbagik Modern Market which since 2013 has stood about one kilometer at south of the old market. Local government used loan sceme from Government Investment Center to build Modern Masbagik Market. But the project was considered stagnant and wasted (Lombok Today, May 11, 2014. Pasar Masbagik Modern Mangkrak). Thus, by relocated traders from Traditional Market of Masbagik to Modern Masbagik Market, as well as expanding and renovating the Old Market for new potential investors, the government hopes to optimize the regional assets while creating the convenience of transacting for the people. However, the 
policy was considered to be disadvantageous economically by target groups that are in fact local people, followed by a series of rejection actions.

At the beginning of 2016, the policy began to be implemented. However, up to five months of merchant relocation implementation, kiosks provided by the government had not been fully filled.

Implementation of merchant relocation to the building of Modern Masbagik Market, is interesting stage of policy system seemed like black box to be studied. In addition to this strategic policy for the Government of East Lombok regency, this policy is also very important for the people's economy in Masbagik Sub-district which is actually known as one of the trading centers and is dominated by the merchant community. Implementation may bias while it will have social impacts for traders and surrounding communities. Therefore this study will answer the problem question: How does the implementation bias occur, so that the target group may not be the policy beneficiaries? What are the impacts of target groups and beneficiaries?

This study aims to examine the resource allocation process in policy implementation. In addition, the examination results are followed by identification of the social impacts of the policy implementation. The research output is intended for research report published in the Scientific Journal, as a contribution to the development of applied public policy analysis and the development of policy analysts / policypreneurs that began to be included as curriculum by several universities in Indonesia. For the field of the policy practice, this research is expected to support the policy paper which will be addressed directly to the East Lombok Regency Government, as the academic contribution to the public policy practice. 


\section{LITERATURE REVIEW}

The paradigm that views public policy processes as a linear process has long been neglected. The policy process chart developed by Samodra Wibawa tries to describe the Eastonian system's approach to the political system by identifying a number of dynamic processes that may occur in the political system before public policy is generated as output systems (Sukmayeti, 2004: 20).

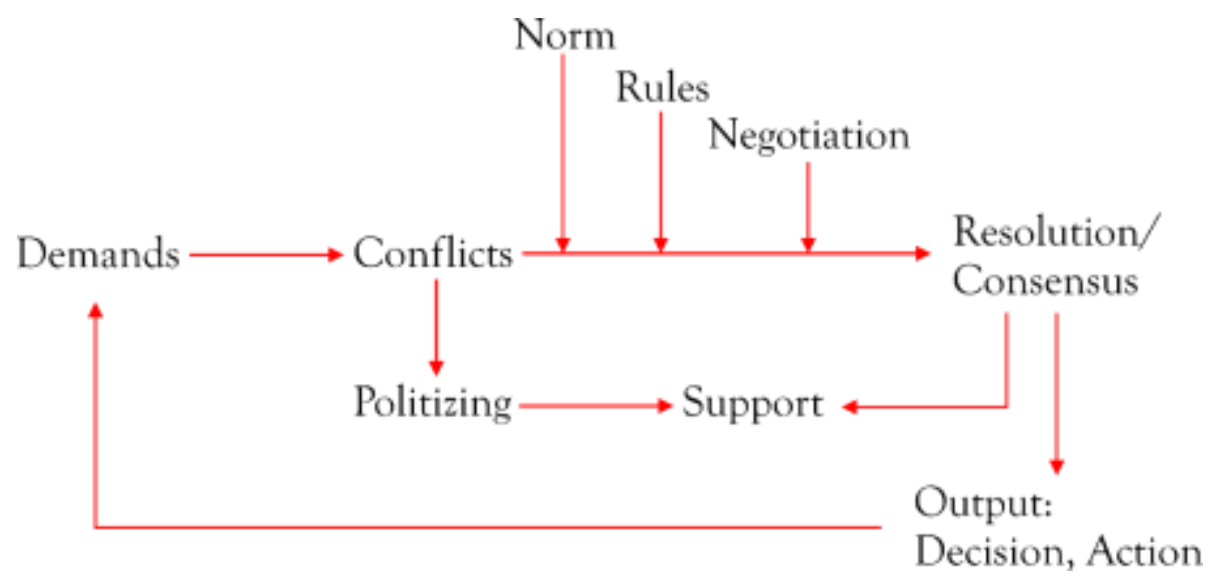

Figure 1. Chart of Policy Process by Samodra Wibawa

This perspective furtherly strengthens the concept of policy change (public change) in the academic domain. A good advocacy (Topattimasang, Fakih and Rahardjo, 2007: 47) is intentionally and systematically designed to push for change in content, management and prevailing legal culture.

Parsons gave the idea of a policy change by distinguishing two policy areas, the scope of policy and the scope of its organization (Putra, 2003: 115). He formulates approaches to see both aspects of change, one of which is organizational change. Meanwhile Maggio 
and Powell describes that organizations will experience three mechanisms of change: (1) coercive, due to strong pressure from other organizations to change public organizations, (2) mimetic, changes due to organizations imitating other organizations, and (3) normative, where change is due to the desire to adapt to the environment (Putra citated to Parsons, 2003: 117-118)

Sabatier and Mazmanian (in Theodoulou and Cahn, 1995: 154) formulated a number of non-legal variables affecting policy implementation. Among them are socioeconomic and technological conditions, attitudes and resources of constituent groups and commitment and leadership skills of executing officials. The socioeconomic conditions create four forms of influence on implementation, specifically: (1) the relative perceptions of the importance of the problem are answered by the policy, (2) differences in local socio-economic conditions on the importance of the problem solved, (3) support on regulations orientated to environment and labors protection, has a correlation to the economic feasibility and importance of the target group in overall economy, and (4) changes or lack of technological change occupy an important role.

The behavior and resources of the constituent group may also affect policy implementation in three ways: (1) through membership and financial resources, (2) providing views on decisions of public institutions and providing additional resources for implementing agencies, (3) critical to the performance of implementing agencies through public opinion campaigns as well as direct interaction with legislative members. While commitment and leadership skill of the executives can influence policy implementation through two forms: (1) officials' choices on the direction and ranking of objectives of the policy, and (2) the skills of officials to realize their options.

Policy implementation is also considered as the stage in which the government and the implementing agency are not single actors. 
The involvement of target groups and the large community is a reality. Measurement of target group participation in policy implementation is one of identification: program/participant beneficiaries, appropriate party but not participating and those who decide to exit of implementation process (Rossi, Freeman and Wright, 1979: 131). The indicators assist to describe of how the resources flow from the target group to the resources released by the government and thus determines the picture of the policy implementation. The implications are a number of policy implementation challenges faced by implementing agencies. Charles O Jones (Jones, 1984: 166) formulated lists a number of policy implementation challenges that can be in the form of defining and continuing throughout the policy process and the inconsistencies of interpretation of the program objectives.

The complexity of policy implementation potentially permits the results policy bias. Dunn supposed a basic in assessing the implementation and impact of policy by which analysts ought to understand that target groups are not always beneficiaries (Dunn, 2000: 514). That is, the target group is not necessarily those who were determined to obtain the benefits, yet might be the target group received a loss or become a group of sufferers.

There are many approaches to the analysis of public policy implementation. One of them is social auditing or social assessment. The process monitored in a social assessment consists of two types: diversion and transformation of resource. Resources diversity shows how input resources are drawn and diverted from target groups as well as from beneficiaries as a result of the passage of resources through the administrative system. Resource transformation is indicated by the difference in resource meaning for program implementators and target groups thus to increase (or weaken) the impact on receiving groups (Dunn, 2000: 538-539). Dunn also lists 
the form of policy resources ie Time, Money, Personnel, Material Tool (Dunn, 2000: 515). So social auditing on implementation should have implications on the impact assessment of who the target group is and who the beneficiary or group is, how (the form or amount) of benefits or losses received by the target group and how (the form or amount) of benefits received by the beneficiaries or losses received by the sufferers group.

The social impact measurement model is relatively more developed in practice. A number of organizations or institutions issued different concepts and indicators. The International Association of Impact Assessment (IAIA) for example, develops the concept of social impacts as: (1) The way people live - how they live, work, play and interact with each other everyday, (2) Their culture - the beliefs, customs, values and language or dialect that they shared, (3) Their community - solidity, stability, characters, services and fascilities, (4) Their Political System - the degree to which people can participate in decisions that affect their lives, the degree of democratization that occurs, and resources available for the purpose, (5) Their environment - the quality of air and water used by humans, the availability and quality of the food they eat, the extent of the damage or risk, garbage and sound that exposes them, the adequacy of sanitation, physical security, and access and control over resources, (6) Health and happiness - health is a condition physical, mental, social and spiritual happiness and not just the absence of illness, (7) property and personal rights - whether a person is economically affected or suffered of personal destruction that could comprise interference to their civic determination, (8) their doubts and aspirations - their perception about security, their concerns about the group future, and their aspirations for their future and their children. (Vanclays, 2003: 8). 


\section{RESEARCH METHODS}

The study is located in Masbagik Subdistrict, East Lombok Regency, West Nusa Tenggara Province. The indicators used in this research are the Diversity and Resource Transformation, as an indicator of the social auditing approach model and the social impact assessment indicator developed by the International Association for Impact Assessment. Data collection techniques use (1) observation and asking a number of questions and recording the observation results in field notes, (2) Semi-structured Interviews and, (3) Tracking Document Data.

The informant is one Community Leader from the village which is directly adjacent to the Market where its citizens are mostly traders in the old market, one Market Security Officer as well as in charge of market charge collector, Trader (determined by purposive and snowball sampling of six persons) represented by daily wet materials traders and common dry material traders, one person of new traders and one person of carrying labor in the market.

Data analysis techniques use the Stakeholder Analysis techniques and Secondary Data Review in the form of written documents. The approach used is social auditing approach and social impact assessment. The data obtained is interpreted to lead to conclusions about the implementation bias and the impacts experienced by both target groups and beneficiaries.

\section{RESULTS AND DISCUSSIONS}

This study describes the forms of resources allocated to traders and relocated citizens as a result of market revitalization policies. All traders in the revitalized market were transferred to a new location which is actually Modern Masbagik Market building that had been 
10 discontinued to be operated due to lack interest of prospective rented traders in that location. With the revitalization of the old market, the removal of all traders makes this market building utilized.

Some of the policy resources allocated by the Government of East Lombok Regency in this policy are:

a. Personel: including those who are given responsibility and are involved in implementing the policy. Revenue Service Office, Financial, Asset Management and Trade Office and hierarchy to market level are responsible in implementing this policy. While officials in the related areas include Head of District, Head of Village, Masbagik Police Chief, head of SubUrbanvillage and community leaders have the duty of helping to create appropriate social conditions for the success of this policy in its territory. Acceptance by groups of merchants and citizens displaced by the widening of new markets is crucial to the successful implementation of this policy.

b. Time: the district government of East Lombok allocated a year to implement this policy preliminary by socialization where the traders and citizens knew the existence of the policy through three times of socialization at the District Government Office until the process of bargaining between the merchants along with citizens and the government related new location which was considered fewer strategic. Deadline of emptying market was October 2015 although there was a process of negotiating.

c. Financial:The money allocated to the target group is only a compensation of the value of the building to the people whose homes were evicted as the implications of market expansion. As for traders, there is no compensation of money other than the provision of stalls. Each stall or kiosk is accompanied by a free dudukan (locating the goods to sell) certificate and does not need to be renewed, it just needs to be prolonged every 5 years 
and can be passed on by their inheritor. As for the stores, the government only gives the accomplishment of rent which is wider in size and newer conditions in the new location. This rental price is higher than at the old location. While the cost of moving goods and other operations at new selling locations, all come from the merchants.

d. Material Tools: Revitalize the market with the implications of market building renovation, using material tools as budgeted by the government of East Lombok Regency in 2017. New kiosk and shop-house in new buildings can be accessed by old traders who sell dry products using new lease agreement and new rental rates (no subsidies for old merchants). While the location of the new traditional market used Masbagik Modern Market building that has been established since 2013 and has not been effectively used.

The process of relocating traders to new traditional markets involves the distribution of stalls and kiosks for relocated traders. The stalls and kiosks are distributed by gambling method to avoid strategic place orientated conflict. With this method, some parties feel disadvantaged while others been fortunated when compared to the place they sell in the traditional market renovated. As a result, some traders choose to stop selling even though the district government of East Lombok still provides certificates that are valid for five years and can be inherited by an extension each year. The certificate is commonly known as a surat dudukan by traders even though it is formally written "Recommendation of Basis Place". This certificate becomes the basis for Market managers to collect retribution or commonly referred to as uang dudukan by traders to the place of selling as well as cleaning service each day. If trader does not use or open a stall on a particular day, then he'she is not levied. But even though the government provides free facilities to traders who are 
evicted with some facilities such as (1) only need to be renewed each year and (2) can be inherited to the children, many traders were unenthusiastic to sell in new locations.

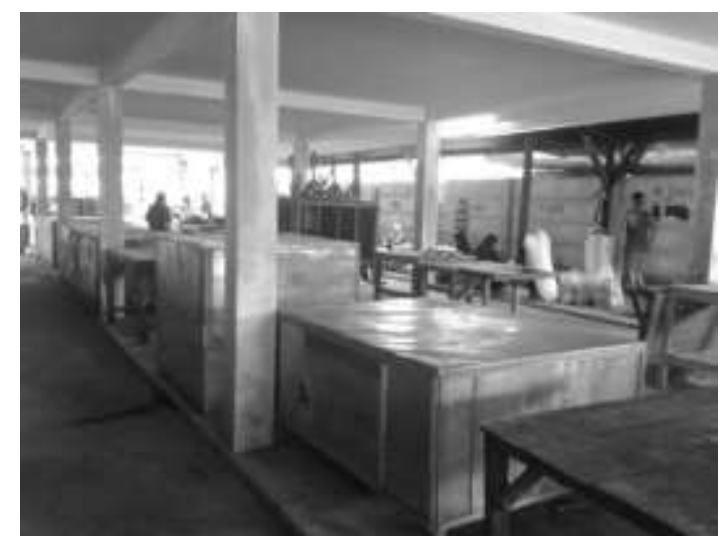

\section{Figure 2. Empty Meat and Poultry Stalls.}

According to market security guard, the informant who are assigned to collect stands every day, when traders do not occupy their stalls consequently they could not shift them to others because there is a clear certificate. Reasonably then the stalls/ kiosks quota that has been written the owner's name, could be empty if the owner does not sell. This is conveyed by informant, because the government wishes to maintain the resources allocated to the merchant targeted. Except for Stores that are leased and must be renewed each year at a greater rate than uang dudukan. For store rental, according to the informant, it was more accessible to traders with larger capital and dominantly come from non-evicted traders. 


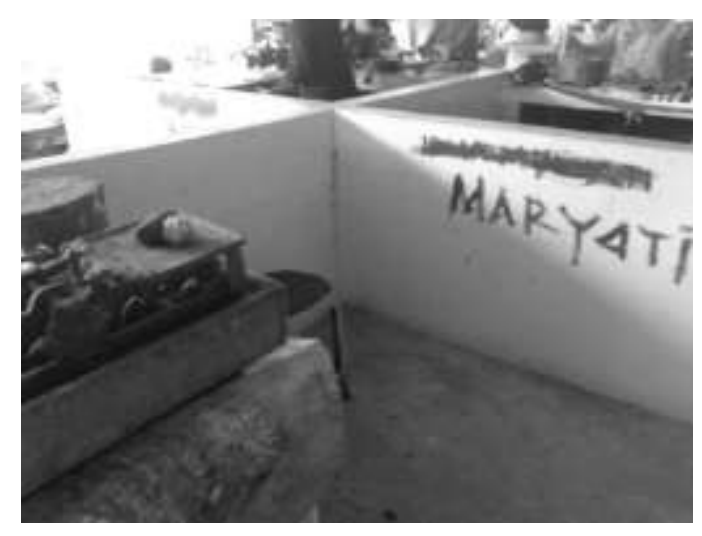

Figure 3. Stall with Owner's Name written on wall to Avoid Conflict.

With larger capacity, new traditional markets also accommodate traders with new or non-relocated status. They come from villages around the market even from several other districts around Masbagik considered the most crowd of trading activities place in this regency. According to informants, many traders who had not been accommodated in the old Masbagik market, feel happy and interested even actively selling in the new market. The new market accommodates 1400 merchants compared to the old market which can only enclose about 600 merchants. Even if more than 600 traders used to be, then most of them were spilled in the market yard to the sidewalk so the old market looked disordered and dirty so the government noticed need to be moved to a new location recently.

In addition, with the current wider stalls/kiosks in new markets, the government of East Lombok hoped traders experience more comfort and market conditions are not too disordered. While the quality of the buildings and the immensity of stalls they get now, it is not supplementarily important than the distance they need to reach the market and the strategic location that is required for the 
most critical value of income they received each day from the profit of selling. This is because traders need to prepare additional transport costs to leave each day while income still does not similar with at the old location and also buyers were still very few who regularly to the market every day, and even then they have to complete with the increasing number of spontaneous vegetable stalls in the villages behind the unenthusiastic people to go to the market looking for daily needs.

The relocation of traders from traditional markets which have been renovated into modern markets has resulted in some adjustments to various types of community employment activities. Indeed local government shifted the place to sell goods, but then some economic life adjustment occured at the new market. Some groups get benefits and other groups are disadvantaged.

Government relocated all types of goods sellers. Although the government of East Lombok regency promised that dry material traders could re-occupy the old location that became modern, in fact the dry products traders refused to move. The reasons are diverse: (1) they are forced to make leasing contracts with new patterns and price list that in fact are more expensive because there is no subsidies for old traders, (2) their customers are people who every day shop the wet products. They assume, if they re-occupy the modern market but separate with wet products traders, then the possibility of buyers to see their goods will be lesser because the wet products needs are the most intense every day sought by buyers, (3) buyers already know the location of traditional markets so that if they are moved or requested to move back to the old location, then the selling conditions they face are starting from beginning, while adjustments experience at new location led some of them got lose even decide to stop selling.

While the beneficiaries, with the relocation to a new location then open the opportunity for: (1) residents in the neighborhood of 
new locations to work, trade (due to the capacity of traditional markets which reached 1400 traders than the old market of only about 600 traders only) or increased other economic benefits such as building a shop opposite to the market, undergoing a motorcycle taxi or cidomo (traditional cart of Lombok dragged by horse) driver even selling the land at a much higher price when new traditional markets begin to operate; (2) residents around the old location open a vegetable stall and basic food in their homes as a result of the many people who are unwilling to go to the market every day because they have to provide some transport money to go to the market. For residents, it would be more efficient if shopping at a neighbor's vegetable stall compared to the market with the cost of motorcycle taxi or cidomo about ten thousand rupiahs while having to shop for a few saving. Shopping at the neighbor's vegetable stalls will be more efficient and get fresh ingredients every day even though there will be a difference of 500-1000 rupiahs for each item they buy. (3) ojek and cidomo, with a pre-paid system, due to the large number of market traders and traders in villages that live far away from the market, creating new opportunities for motorcycle taxi drivers and cidomo drivers. As told by Aunt Uyung who opened a vegetable stall on the terrace of his house, he paid motorcycle taxi per day for ten thousand rupiahs to go and return from the market with his merchandise.

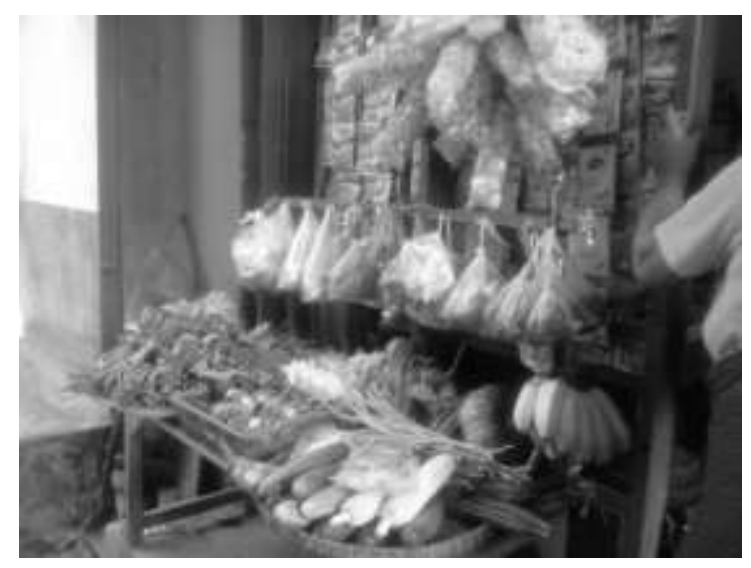


 \\ Figure 4. Spontaneous Kiosk on Terrace Home, Capturing Relocation Opportunities}

Indeed, there are some who received a negative impact. Tuaq Sahul for example. He is a carrying labor who is usually paid by a buyer to raise their groceries or by traders to bring merchandise to their stalls or kiosks and earn two thousand rupiahs or more depending on the weight of the goods or the giver's initiative. When the market location is moved from the old location next to the village, he have to walk about thirty minutes to a new market, because he can not drive and have no vehicle. And even then in a new location he will compete with motorcycle or taxi drivers or coachman of cidomo who often provide freight services for prospective passengers. Thus labor such as Tuaq Sahul become very disadvantageous: distant market locations to go without ownership of vehicles and rivals with motorcycle taxi drivers or cidomo drivers who carry the role of transport as well. Finally, the income such as Tuaq Sahul is certainly much decreased while the sacrifices are getting bigger to reach the location of his work.

In addition to labors such as Tuaq Sahul, there are some traders who ultimately really lose money. Inaq Aen is a merchant who is forced to stop selling at all. He then switches to the traditional food merchandise he sells on his own house terrace. According to her, selling traditional food on the terrace of her house is more profitable than continuing to trade clothes in the new market. Coincidentally his daughter set up a Quran Educational Park (TPA) in her yard and she sells snacks and traditional Sasak food. Students of TPA even parents become her loyal customers. He have not to pay a levy or wait for a clothing buyer who does not have to be there every day, because now he sells on his own terrace and every day except Sunday. In fact, 
under certain conditions she held the rest of her old clothing wares on the terrace of his house.

The same thing happened to Aunt Nihayah. She sells snacks since in the old market. Similarly, when she had to move to a new market. She acknowledged that there were some changes to the sales patterns she was implementing right now because she was experiencing a decrease of income after being relocated. Once in the renovated market, her customers are small traders who buy snacks in wholesale. She was not motivated to open a small kiosk at home when she came home from selling every afternoon. But now, she was enforced to function windows and terrace of his house to sell snacks, and dominate buyers are retail buyers. Otherwise, she admits that her income is not sufficient for her growing household needs, whilst her income decreases as it is difficult to get customers as before. She used to have a break after selling, but not now. She used to serve more wholesale buyers, but now she should to target retail buyers at house.

Another case with Hajjah Sahmini experience. She sells shoes, sandals and school bags as dry goods. Since being moved to a new location, she admits her turnover has dropped dramatically. She told that she was not able to rent kiosk as large as before because in a new location she found it was not easy attract many customers. Actually she gets kiosks and stalls quota from the district government. But because of the gamble system, she gets a less strategic kiosk. Therefore then she chose to move to a strategic place with the consequences she must rent to the owner. Fortunately she has a family who get a strategic kiosk but decided not to continue trading, so she can rent the kiosk with very good price.

Some adjustments related to the way of selling or economic life of citizens as the implications of the relocation of old Masbagik market traders, have a diverse impact on their expectations and perceptions of their lives as a whole. Some have better expectations of finding 
economic value opportunities from moving market locations, some groups are building new hopes by changing their economic orientation to previous economic conditions and partly being forced to accept the diminishing and even loss of their expectations of the current selling conditions.

\section{CONCLUSION}

Old Masbagik market revitalization that has implications on the relocation of traders and residents whose houses are exposed to market expansion illustrates that:

a. The resources allocated by the Government of East Lombok District have expanded the scope of the beneficiaries. There were new merchants who get a chance at a new location. While old traders, although some are reluctant to sell and even decide to stop selling, still certainly get a replacement stall.

b. Relocated traders and residents responded widely to the material resources allocated by the government. For the government the provision of newer, cleaner and more spacious, stalls with free and inherited stand certificates is a valuable resource for traders. But for traders, the location of selling is much more valuable because it determines the interest of consumers to shop to market.

c. Impacts on traders and labors relating to market relocation: (a) traders experiencing a decline in the economic resources of the family, or vice versa (b) there are new traders who find opportunities to open their trading businesses; (c) the origin or change of business type in trader households (d) supporting professions such as carrying labors facing cost increases in their work, or vice versa (e) profession 
(transportation services) of motorcycle/taxi drivers or cidomo coachman who get the opportunity to get passengers with a pre-paid pattern of daily traders who open business in the villages that are now far away from the new market.

East Lombok Regency government needs to understand the transformation of resources where perceptions of the value of stalls and free and inherited selling basis certificate facilities are no more valuable than the continuity of the merchant's income due to the market distance from the consumer. For further, the local government needs to provide subsidized daily retribution to traders so the traders still benefited during the process of adjustment and customer achieving.

\section{REFERENCES}

Centre For Good Governance. (2005). "Social Audit: A Toolkit A Guide for Performance Improvement and Outcome Measurement" Director General \& Executive Director, Centre for Good Governance Dr MCR HRD IAP Campus, Hyderabad.

Charles O Jones. (1984). An Introduction to The Study of Public Policy. Brooks/Cole Publishing Company. Monterey. California.

Fadillah Putra. (2003). Paradigma Kritis dalam Studi Kebijakan Publik. Pustaka Pelajar bekerjasama dengan Universitas Sunan Giri. Surabaya.

Fischer, Frank; Miller,Gerald J ; Sidney, Mara S (Eds). (2007). Handbook of Public Policy Analysis: Theory, Politics and Methods. CRC Press. New Jersey.

Frank Vanclay. (2003) International Principles For Social Impact Assessment.Impact Assessment and Project Appraisal, Volume 21, Nomor 1, halaman 5-11, Beech Tree Publishing, 10 Watford Close, Guildford, Surrey GU1 2EP, UK

Geva-May, Iris. (2005). Thinking like a policy analyst: policy analysis as a clinical profession. Palgrave Macmillan. New York.

Lombok Today, 11 M ei 2014. Pasar Masbagik Modern Mangkrak.

Moran, Michael; Rein, Martin; Goodin, Robert E (Eds). (2006). The Oxford Handbook Of Public Policy. Oxford University Press Inc., New York. 
Peicheva, M iroslava; Kraeva - Miteva, Albena; Harizanova, Hristina. Study of the Social Audit and Standards for Social and Environmental Responsibility - Case Study of Bulgaria.. Economic Alternatives, 2017, Issue 3, pp. 449-474.

Pekkonen, Anu; Sadashiva, Manjunath. (2010). Social Audits. Civicus and PG Exchange. retrieved from http://civicus.org/documents/toolkits/PGX_H_Social\%20Audits.pdf

Rossi, Peter H; Howard E Freeman; dan Sonia R Wright. (1979). Evaluation A systematic Approach. Sage Publications. Beverly Hills. London.

Stone, Deborah. (2012). Policy Paradox: The Art Of Political Decision Making. Third Edition. WW Norton \& Company, USA.

Sukmayeti, Evi. (2004). Proses pemekaran Daerah Kota (Analisis Interpretatif Terhadap Agenda Setting Hingga Implementasi Kebijakan Pemerintah Kota Pekanbaru Membentuk Kecamatan Dan Kelurahan Baru Serta Implikasi Public Dalam Prosesnya). Skripsi. Jurusan IImu Adminisrasi Negara. Universitas Gadjah Mada. Yogyakarta.

Theodoulou, Stella Z dan Matthew A Cahn (ed). (1995). Public Policy The Essential Reading. Prentice Hall, Inc. New Jersey.

Topatimasang, Roem; Mansour Fakih dan Toto Rahardjo. (2007). Mengubah Kebijakan Publik. INSISTPress. Yogyakarta. 